Amasya Ilahiyat Dergisi - Amasya Theology Journal

ISSN 2667-7326 | e-ISSN 2667-6710

Aralık / December 2019, 13: 51-77

\title{
Tefsirde Erkek Egemen Bir Yorum ve Değerlendirmesi: ez-Zuhruf 43/18 Âyet-i Kerîmesi Bağlamında Bir İnceleme
}

\section{A Male-Dominant Interpretation and Evaluation in Tafsir: Review in the Context of az-Zukhruf $43 / 18$ of the Quran}

\author{
Recep Orhan Özel \\ Doç. Dr., Amasya Üniversitesi, İlahiyat Fakültesi, \\ Tefsir Anabilim Dalı \\ Associate Professor, Amasya University, Faculty of Theology, \\ Department of Tafsir \\ Amasya, Turkey \\ orhan.ozel@amasya.edu.tr \\ orcid.org/0000-0001-8094-2337
}

\section{Makale Bilgisi / Article Information}

Makale Türü / Article Types: Araştırma Makalesi / Research Article

Geliş Tarihi / Received: 16 Eylül / September 2019

Kabul Tarihi / Accepted: 30 Ekim / October 2019

Yayın Tarihi / Published: 30 Aralık / December 2019

Yayin Sezonu / Pub. Date Season: Aralık / December

Sayı / Issue: 13 Sayfa / Pages: 51-77

Atıf / Cite as: Özel, Recep Orhan. "Tefsirde Erkek Egemen Bir Yorum ve Değerlendirmesi: ez-Zuhruf, 43/18 Âyet-i Kerîmesi Bağlamında Bir İnceleme [A Male-Dominant Interpretation and Evaluation in Tafsir: Review in the Context of ez-Zukhruf 43/18 of the Quran]". Amasya Ilahiyat Dergisi-Amasya Theology Journal 13 (December 2019): 51-77.

https://doi.org/10.18498/amailad.620378.

İntihal / Plagiarism: Bu makale, en az iki hakem tarafından incelendi ve intihal içermediği teyit edildi. / This article has been reviewed by at least two referees and scanned via a plagiarism software. 
52 | R. O. ÖZEL / Tefsirde Erkek Egemen Bir Yorum ve Değerlendirmesi: ez-Zuhruf 43/18 Âyet-i Kerîmesi Bağlamında Bir İnceleme

Copyright $\odot$ Published by Amasya Üniversitesi, İlahiyat Fakültesi / Amasya University, Faculty of Theology, Amasya, 05100 Turkey. All rights reserved. https://dergipark.org.tr/amailad.

\section{A Male-Dominant Interpretation and Evaluation in Tafsir: Review in the Context of az-Zukhruf 43/18 of the Quran}

\section{Abstract}

Interpretation is an effort to reveal the goal and desire of almighty Allah who reunites message with the human. No doubt that the Qur'an's first commentator, Prophet Muhammad (pbuh) performed his duty under the control and observation of divine inspiration. This situation makes his role and position unarguable in the interpretation. Any mufassir who has not such precedence uses his skills like information, ability, experience, and mind. Again, a person, in any case, is affected by historical and cultural conditions of the period he lives in. Interpreter's partly prudent attitudes and efforts to remain loyal to procedure and method attest to this fact. Even so, it is impossible to completely elude from the human factor in interpretation in spite of all precautions and principles. In our opinion, mufassirs' comments on the azZukhruf 43/18 of the Quran represent one of the sharpest examples of this situation. Related versicle of the Quran has made jahiliyyah mentality that underestimates women a current issue; again, the same versicle refuses the beliefs which accept that angels are the daughters of Allah through this mentality. However, the eighteenth versicle that vilifies a superstitious belief has been discussed to male-dominant and partially sexist comments. Negative provisions on women give an impression as it was related provisions belong to Allah when relevant comments are analyzed. For us, these comments are the reflection of the male-dominant culture that mufassirs grow in. Related comments of mufassirs were scrutinized and evaluated in this paper; we also have concluded that the versicle figures jahiliyyah mentality in fact.

\section{Summary}

The unique goal of each intellectual who interprets Allah's book is to reveal the meaning that is referred to by the wording of the Quran. However, definitions of mufassirs are not at the same level as a prophet who could receive divine inspiration from Allah at any moment and communicate with the angel of divine inspiration. Again, as is being in the prophet, there is no divine mechanism that can correct mufassirs in case of an error and mistaking. Contrarily, there is an understanding process with his knowledge, culture, and mentality in his explanation and comments. This circumstance shows that 
R. O. ÖZEL / A Male-Dominant Interpretation and Evaluation in Tafsir: Review in the Context of az-Zukhruf 43/18 of the Quran I 53

mufassir, in any case, is affected by social and cultural conditions around him. Professional trends, sectarian reflexes, and differences in comments of mufassirs who have worked through on versicles of the Quran are the epitomes of the human fact in interpretation. In this case, it is understood that it is not possible to completely elude related historical conditions for almost all the intellectuals. For us, one of the epitomes of this fact is seen in the interpretation of the eighteenth versicle of az-Zukhruf, 43/18. We can observe when looking at comments for related versicle that almost all the comments are under the influence of male-dominant mentality. Related comments have transformed into an interpretation style that can occasionally be characterized as sexist. Concerning the general acceptance in interpretations, Arabs believed that angels are Allah's daughters. This is impossible; it is out of line to associate Allah to a creature who is in insolvency and deprivation for explaining oneself. Owner of sardonic evaluations about women in those comments is accepted as Allah. Accordingly, also the interpretations of mufassirs are parallel to this line. Almost all the mufassirs have made mental efforts about why girls cannot be attributed to Allah. Unfortunately, that they have inclined to comments which play down women. Swearing has reached the peak by both identifying this helpless and worthless creature with the gender of angles and describing them as Allah's daughter. Comments have turned into a point of view that underestimates and humiliates girls by a male-dominant mentality and gained nature that legitimates idioms such as petticoat.

Again, the general attitude and opinions of mufassirs have been effective in preference and translation of meaning authors. It is seen when we looked at meanings in the context of related eighteenth versicle that the same situation is repeated except some exceptions.

Mufassirs can mistake in their comments for several reasons. It is an obligation to criticize controversial approaches in our resources when we think that the smallest opportunity is exploited by great rumbles in Anti-Islam propagandas today. However, sardonic approaches for a woman against man are a perspective belongs to jahiliyyah. It is not pointed to see such approaches as if they belong to Allah.

According to us, mufassirs have drifted with the tide of male-dominant climate in their period. Thus, their comments have continued on this axis as from Qatâda, mufassir of Tâbiîn period. Male-dominant conditions which mufassirs have grown in surround their world of thought like a lamp glass. This framework is an indicator that shows us how the interpretation process intertwines with humanitarian tendencies. While these comments can be seen in interpretation texts, the general run of mufassirs has not talked about the value 
54 | R. O. ÖZEL / Tefsirde Erkek Egemen Bir Yorum ve Değerlendirmesi: ez-Zuhruf 43/18 Âyet-i Kerîmesi Bağlamında Bir İnceleme

of women in both the Quran and the sunna. But there are many examples which show value of women in both Quran and interpretation heritage. For example, it has never been referred that related sardonic comments do not accord with versicles which leave behind each kind of secular degree; "In the sight of Allah, your most valuable is the person with most taqwa" "We have created human in the most perfect way".

For us, az-Zukhruf, $43 / 18$ consists of a definition of jahiliyyah mentality. Related versicle was inspired to vilify jahiliyyah mind that attributes child to Allah by describing angles as Allah's daughters; besides, the same versicle was also inspired to reveal a discrepancy in terms of their mentality. Quran, in many of versicles, hushes up jahiliyyah mind that buries their daughters alive and feels shame for having a daughter. They did not harm in associating female gender to Allah within the dad-daughter tie. Quran reveals the fault of their belief through flinging in their face. It is possible to evaluate this within the scope of a purpose such as giving unenlightened food for thought or breaking their routine. Thereby, it has been provided people who accept angles as Allah's daughter and hates daughters as many as possible. Context of versicle is compatible with versicles of the Quran which attribute value and supremacy to faith and mention that human has been created most perfectly without noticing being female and male. Now then it is impossible to approve related negative interpretations on women. There is also not a hadith that supports related comment of the versicle.

In this paper, evaluation of related interpretations which reflect to Turkish meanings was made besides revealing how associated versicle needs to be understood.

Keywords: Tafsir, Chapter Zukhruf, Woman, Gender, Jahiliyyah.

\section{Tefsirde Erkek Egemen Bir Yorum ve Değerlendirmesi: ez-Zuhruf, 43/18 Âyet-i Kerîmesi Bağlamında Bir İnceleme}

Öz

Tefsir faaliyeti, vahyini insanla buluşturan yüce Allah'ın maksat ve murâdını ortaya koyma çabasıdır. Şüphesiz Kur'ân'ın ilk müfessiri Hz. Peygamber (a.s.) bu vazifesini vahyin denetim ve gözetimi altında gerçekleştirmiştir. Bu onun (a.s) tefsirdeki rol ve konumunu tartışmasız kılmaktadır. Böyle bir ayrıcalığa sahip olmayan herhangi bir müfessir ise bilgi, beceri, tecrübe ve akıl gibi yeteneklerini kullanır. Yine bir insan olarak yaşadığı dönemin tarihi ve kültürel şartlarından da az ya da çok etkilenir. Onların tefsirdeki yer yer ihtiyatlı tutumları, usûl ve yönteme bağlı olma çabaları bu olguya delâlet eder. Yine de tüm tedbir ve ilkelere rağmen tefsirde insan unsurundan tamamiyla siyrılmak 
R. O. ÖZEL / A Male-Dominant Interpretation and Evaluation in Tafsir: Review in the Context of az-Zukhruf 43/18 of the Quran I 55

mümkün olmaz. Kanaatimize göre müfessirlerin ez-Zuhruf, 43/18 âyet-i kerimesine getirdikleri yorumlar, bu durumun en bariz örneklerinden birini temsil etmektedir. İlgili âyet-i kerime öncesi ve sonrasıyla câhiliye anlayışının kadını küçümseyen tavrını gündeme getirmekte ve bu tavır üzerinden de melekleri Allah'ın kızları olarak kabul eden inanışlarını reddetmektedir. Ancak batıl bir itikadı yeren on sekizinci âyet-i kerîme birçok tefsirde kadınla ilgili erkek egemen kısmen de cinsiyetçi yorumlara konu olmuştur. İlgili izahlar okunduğunda kadınla ilgili gündeme getirilen olumsuz hükümler Allah'a aitmiş gibi bir izlenim vermektedir. Bize göre bu yorumlar müfessirlerin içinde yetiştiği erkek egemen kültürün yansımasıdır. Bu makalede müfessirlerin ilgili yorumları incelenip değerlendirilmiş ve âyetin daha isabetli bir zeminde anlaşılması gerektiği ortaya konulmaya çalışılmıştır.

Anahtar Kavramlar: Tefsir, Zuhruf sûresi, Kadın, Cinsiyet, Cahiliye.

\section{Giriş}

Hz. Peygambere (a.s) vahiy yoluyla iletilen Kur'ân metni hem lafzen hem de manen Allah'a aittir. Doğrudan ya da dolaylı âyet-i kerîmeler Kur'ân lafzının Allah'a aidiyetini teyit etmektedir. ${ }^{1}$ Bu metnin insanlara tebliğ ve tebyin görevi öncelikle Allah Resulüne tevdi edilmiştir. O (a.s), Allah'ın kendisine verdiği yetki ile Kur'ân'ı okuyarak, açıklayarak ve yaşayarak insanlara talim etmiştir. Durum ve ihtiyaçlara göre vahiy alan, ilahi tashih ve gözetim altında bulunan Allah Resulünün tefsirdeki otoritesi tartışmasızdır. Çünkü son ilâhi kitap onun kalbine indirilmiş ve onun aracıllı̆̆ıla insanlıkla buluşturulmuştur. Hz. Peygamberin (a.s) ahirete intikaliyle vahiy sona erse de tefsir ameliyesi son bulmamış, âlimler bu vazifeyi bugüne kadar ifa etmişlerdir.

Allah'ın kitabını tefsir eden her âlimin yegâne hedefi lafızdan kastedilen manayı ortaya koymak veya murâd-ı ilâhiyi açığa çıkarmaktır. Bu cümleden olmak üzere tefsir, "Müşkil olan lafızdan murad edilen manayı ortaya çıkarmaktır." ${ }^{2}$ şeklinde tanımlanmıştır. Ancak şu bir gerçek ki, müfessirlerin izahları, Allah'tan her an vahiy alabilen, vahiy meleği ile iletişim kuran bir peygamberin beyanlarıyla aynı düzeyde değildir. Yine Hz. Peygamber'de olduğu gibi hata ve yanılma

1 Yunus, 10/15; Tâhâ, 20/114; el-Kıyâme, 75/ 16-19.

2 Ebü'l-Fazl Cemâlüddîn Muhammed b. Mükerrem b. Manzûr, “Fsr”, Lisânü’lArab (Beyrut: Dâru Sadr, h. 1414), 5: 55. 
56 | R. O. ÖZEL / Tefsirde Erkek Egemen Bir Yorum ve Değerlendirmesi: ez-Zuhruf 43/18 Âyet-i Kerîmesi Bağlamında Bir İnceleme

durumlarında müfessiri tashih edecek ilahi bir mekanizma da söz konusu değildir. Aksine müfessirin izah ve yorumlarında kendi bilgi, kültür ve anlayışlarının eşlik ettiği bir ictihad süreci söz konusudur. Bu da tefsirin müfessiri kuşatan sosyal ve kültürel şartlardan şu veya bu şekilde etkilenme gerçekliğini beraberinde getirmektedir. Tarih boyunca aynı kitabın âyetleri üzerine kafa yoran müfessirlerin yorumlarındaki farklılıklar, meslekî eğilimler, mezhebî refleksler tefsirdeki insan unsurunun somut örneğidir. ${ }^{3}$

Peygamberin yetki ve otoritesini hâiz olmayan bir insanın vahyi yorumlamadaki meşruiyeti, etkisi ve rolü nasıl olacaktır? Bu bağlamda kaynaklarda yer alan sert söylemlerin ve akıl-nakil tartışmalarının sadece felsefenin ilgi alanında kalmayıp tefsire de taşınması, özünde aynı sorunu aşma çabasının bir sonucudur. Bu da tefsir söz konusu olunca insan unsurunun vahyin anlamlandırılmasında alması gereken konum ve rolün boyutlarıyla ilgilidir. Rivâyet ve dirâyet taraftarlarınca getirilen argümanlar gerçekte bu soruna çözüm aramaktadır. Nitekim tefsirde mutlak anlamda rivâyeti savunanlar aslında reyin vahye beşerî bir müdahale anlamı taşıdığı kanaatinde olmuşlardır. Sonuçta bu tartı̧̧malar makul bir zemin bularak gerekli ilimlerle mücehhez olma kaydının benimsenmesiyle aşılmıştır. Her ne kadar müfessir olmanın şartları bağlaminda uzun listeler oluşturulsa da tefsirde rey ve dirayetin belli şartlar altında meşruiyeti çoğunluk nezdinde kabul görmüştür. Gerçek şu ki, dirâyetin tefsirde rol alması, bir yönüyle önceden var olmayan yeni olgu ve sorunların gündeme gelmesinin zorunlu kıldığ 1 bir sonuçtur. Ancak bu zorunluluk tarihî ve kültürel şartlarla çevrili müfessirin olabildiğince vahyin kapsama alanı içinde kalma sorumluluğunu beraberinde getirmektedir. Tefsir için belirlenen usûl ve esaslar yorum farklılıklarının önüne tamamen geçmese de, mümkün olduğunca murâd1 ilâhi istikâmetinde kalmaya aynı zamanda da keyfi ve aşırı yorumlara engel olmaya yönelik vazifeler ifa etmiştir.

Esasında tefsir geleneği içinde önemli eserler vermiş bütün ilim adamları vahyin aşkınlığı karşısında kendi tarihî gerçekliklerinin farkındadır. Kimi yorumlarının sonunda, "Allahu e'lemu bimurâdihî", "Allahu e'lamü bissavâb" gibi kayıtlar düşmeleri müfessirin izahlarında murâd-ı ilâhîye aykırı düşme riskinin bir ifadesidir. Yahut tefsir

3 Murat Sülün, “Tefsir İlim midir? Nasıl Bir İlimdir?", Tefsir Nasıl Bir İlimdir?, ed. Murat Sülün (İstanbul: Ensar Neşriyat, 2011), 23. 
R. O. ÖZEL / A Male-Dominant Interpretation and Evaluation in Tafsir: Review in the Context of az-Zukhruf 43/18 of the Quran I 57

ameliyesinde beşerî mülahazalara dayalı hata ihtimalinin farkında olunduğunun göstergesidir.

Bu nedenle hemen her ilim adamı için söz konusu tarihsel şartların içinden mutlak surette sıyrılmanın mümkün olmadığı anlaşılmaktadır. Bize göre bu durumun somut örneklerinden biri ez-Zuhruf 43/18 âyetinin tefsirinde müşahede edilmektedir. Söz konusu âyet-i kerîme esasen müşriklerin batıl inançlarını red ve zem bağlamında gelmiştir. Zira câhiliye Arapları, putları Allah'a ortak koşma yanında melekleri de Allah'ın kızları şeklinde kabul eden bir inanca sahipti. Kur'ân birçok yerde bu batıl inançların yanlışlığını ortaya koyan âyetlerle doludur. Alabildiğine erkek egemen -hatta kadın aleyhine cinsiyetçi- bir tasavvura sahipken melekleri Allah'ın kızları olarak gören cahiliye inancı da değişik yerlerde yerilmiştir. ${ }^{4}$ Ancak bu meyandaki âyetlerden biri olan ez-Zuhruf 43/18 âyetine getirilen yorumlara bakıldığında hemen hepsinin erkek egemen telakkilerin etkisi altında kaldığı anlaşılmaktadır. Hatta söz konusu yorumlar zaman zaman cinsiyetçi olarak nitelenebilecek yorum biçimlerine dönüşmüştür. İlgili yorumlar okunduğunda, gerçekte batıl bir inancı reddetme bağlamında gelen âyette Allah'ın, kadını iki laf etmekten ve kendini müdafaadan aciz bir varlık gibi nitelediği zannedilmektedir.

Şunu açık ve net bir şekilde ifade edelim ki bu çalışmanın amacı Kur'ân'ın anlaşılması için büyük mesailer harcamış tefsir mirasını günümüz anlayış ve telakkileri üzerinden mahkûm etmek değildir. Yine erkekle kadın arasındaki fıtrî özellikleri görmezden gelen kimi çağdaş söylemleri tasdik etmek de değildir. Bununla beraber müfessirlerin de değişik sebeplerle yorumlarında yanılma ihtimali mümkündür. İslam aleyhine yakalanan en küçük fırsatın büyük gürültülerle istismar edildiği düşünülürse tartışmalı yaklaşımların kritik edilmesinin zorunluluk olduğu da bir gerçektir. Oysa kadını erkek karşısında küçümseyici yahut değersizleştirici yaklaşım, cahiliyenin bakış açısı olup bunun Allah'ın kadın hakkındaki beyanı gibi görülmesi isabetli olmasa gerektir. Bu makalede tefsirler yanında Türkçe meallere de yansıyan söz konusu yorumların değerlendirilmesi yapılacak ve bize göre ilgili âyetin, üstünlüğü takvâ esasına bağlayan, kadını ve erkeği birbirinin örtüsü addeden temel ilkeler mihverinde nasıl anlaşılması gerektiği ortaya konulmaya çalışılacaktır.

4 es-Sâffât, 37/149, 150; ez-Zuhruf, 43/19. 
58 | R. O. ÖZEL / Tefsirde Erkek Egemen Bir Yorum ve Değerlendirmesi: ez-Zuhruf 43/18 Âyet-i Kerîmesi Bağlamında Bir İnceleme

\section{1.a. Tefsir ve Meâllerimize Yansıyan Erkek Egemen Yorumlar}

ez-Zuhruf 43/18 âyet-i kerîme siyak-sibak irtibatı içerisinde incelendiğinde on beşinci âyet-i kerîmeden itibaren şöyle bir anlatım örgüsü içerisinde gelmektedir: Müşrikler Allah'a, yarattığı kullardan pay (cüz) nispet etmişlerdir. Bu durum yaratıcıya karşı açık bir nankörlük olarak nitelenmiştir. Ardından Mekke müşriklerine hitapla, "Yoksa (Allah) yarattıklarından kendine kılar edindi size de erkekleri mi ayırdı?" şeklinde bir soru yöneltilmiştir. Hemen akabinde ise kız çocuğu müjdesi verildiğinde üzüntü ve öfkesi beden diline yansıyan cahiliye erkeği tasvir edilmiş ve ardından araştırmamızın ana temasını oluşturan ez-Zuhruf 43/18 âyet-i kerîme gelmiştir. Söz konusu âyet-i kerimenin metni şu şekildedir: ${ }^{5}$

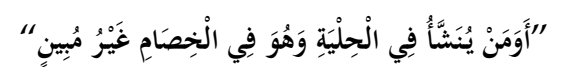

Literal şekliyle dilimize çevirdiğimizde genel kabul gören görüşe göre bu âyet-i kerimenin meâli öncesi ile irtibat kurmaksızın şu şekilde olmaktadır: "Süs püs içinde büyütüleni ve tartışmada kendini ifade etmekten aciz olanı mı (Allah'ın kızları) sayıyorsunuz?"

Uzun bir geçmişe sahip tefsir mirası günümüze değin incelenirse on sekizinci âyet-i kerimedeki "men" ism-i mevsulünün kime ya da neye delâlet ettiği konusunda üç görüşün beyan edildiği görülmektedir. İbn Abbas (ö. 68/687-88), Mücâhid (ö. 103/721), Katâde (ö. 117/735) ve Süddî'den (ö. 127/745) nakledildiğine göre ilgili ism-i mevsulle kastedilenler kadın ya da kızlardır. Yine Katâde'ye ait ikinci bir yoruma göre câriyelerdir. Üçüncü yoruma göre ise putlardır. Dikkat edilirse birinci ve ikinci yorum kadın cinsini ifade etmesi bakımından ayn düzlemde yer almaktadır. Müfessirler arasında pek itibar edilmeyen üçüncü görüş ise İbn Zeyd'e aittir. ${ }^{6}$

ez-Zuhruf, 43/18.

6 Medine tefsir okulunda yetişen Hz. Ömer'in oğlu Abdurrahman'ın âzadlısı Zeyd b. Eslem'in (ö. 136/753) oğlu Abdurrahman b. Zeyd b. Eslem'dir. Babasından ve İbnül-Münkedir'den (ö. 131/749) ilim aldığ1 hatta babasının tefsirini naklettiği ifade edilir. Şemseddin Muhammed b. Ali Ahmed edDâvûdî, Tabakâtǘl-müfessirîn (Beyrut: Dâru'l-kütübi'l-ilmiyye, 2002), 128; Ahmed b. Muhammed el-Ednevî, Tabakâtü'l-müfessirîn, thk. Süleyman b. Salih el-Huzey (Suûd: Mektebetü'l-ulûm ve'l-hikem, 1997), 11; Ömer Nasuhi Bilmen, Büyük Tefsir Tarihi ve Tabakâtüll-müfessirîn (İstanbul: Bilmen Yayınevi, 1973,) 1: 290. 
Önceki ve sonraki müfessirlerin hemen hepsi, "men" ism-i mevsulünü kızlarla ilişkilendirmiştir. Ancak sorun bunun üzerine binâ edilen yorumlarda kendini göstermektedir. Zira bütün yorumlarda ifade doğrudan doğruya Allah'ın kadına ilişkin bir nitelemesi olarak görülmüştür. Böyle olunca genel kabul gören manaya göre âyet; kız cinsinin "Allah'ın kızları" şeklinde bir nispete konu olamayacağı; zira süs püs içinde büyütülen ve tartışmada meram ifade edemeyecek kadar acz ve yoksunluk içinde olan kifayetsiz bir varlığın Allah'a izafesinin hiç mi hiç yakışık almayacağı şeklinde bir anlama bürünmüş olmaktadır. Bu manaya göre kadınlarla ilgili istihfaf edici bu hitab doğrudan Allah'a ait bir niteleme olarak görülmüş ve müfessirler tarafından yapılan yorumlar da bu düzlemde ilerlemiştir. Binaenaleyh müfessirlerin neredeyse tamamı tüm zihni çabalarını kızların niçin Allah'a izafe edilemeyeceği konusuna harcamışlar ve maalesef kadını küçümseyen ve değersizleştiren türlü yorumlara meyletmişlerdir.

Görebildiğimiz kadarıyla söz konusu yorumların önünü açan ilk izah, tâbiîn müfessirlerinden Katâde'ye nispet edilmektedir. Bu konuda Taberî (ö. 310/923), Katâde'den iki ayrı nakle yer vermektedir. Birinci yoruma göre, "men" ism-i mevsulünden kasıt câriyelerdir. Allah onları bu şekilde aşağılamaktadır ve acziyetlerinden dolayı da ifade gücüne sahip değildirler. ${ }^{7}$ Yine Katâde'den nakledilen ikinci yoruma göre ise kadının tartışmada delile dayalı konuşmadaki yetersizliği net bir şekilde ifade edilmektedir. Birçok müfessirin tefsirine aldığı bu ifadelere göre, "Kadın pek az konuşur. $\mathrm{O}$, delille konuşmak istediğinde ise ancak kendi aleyhine konuşur." ${ }^{8}$

Ebu'l-Leys es-Semerkandî'nin (ö. 373/983) belirttiğine göre, kadınlar tartışmada delil ortaya koyamazlar. Çünkü kadın tartışma ve konuşmada erkeğin seviyesine ulaşamaz. ${ }^{9}$

Sem'ânîye (ö. 489/1096) göre, kadın süslenmekle meşguldür. İşlerde kendisine ait bir görüşü söz konusu değildir. Eşyada tasarruf

7 Ebû Cafer Muhammed b. Cerîr et-Taberî, Câmi'u'l-beyân fî te'vîli'l-Kur'ân, thk. Ahmed Muhammed Şakir (Beyrut: Müessesetü'r-risâle, 2000), 21: 579.

8 Taberî, Câmi'u'l-beyân, 21: 580.

9 Ebu'l-Leys Nazr b. Muhammed b. Ahmed es-Semerkandî, Bahru'l-ulûm (b.y.: y.y., ts.) 3: 254. 
60 | R. O. ÖZEL / Tefsirde Erkek Egemen Bir Yorum ve Değerlendirmesi: ez-Zuhruf 43/18 Âyet-i Kerîmesi Bağlamında Bir İnceleme

yetkisi kullanamaz. Tartışmada da sözleri zayıftır. Delile dayanarak çok az konuşur. Konuşmak istese de kendi aleyhine delil getirir.10

Mutezilî müfessir Zemahşerî (ö. 538/1144) de kadının erkek karşısında tartışma yeteneğinin olmadığını, çünkü kadının erkeğe nispetle akıl yönünden ve fitraten eksik bir varlık olduğunu söyler. ${ }^{11}$ Yine ifade ettiğine göre söz konusu Arap müşrikleri "Allah'ın kızları" itikadıyla aslında üç ayrı küfrü cemetmişlerdir. Buna göre onlar Allah'a çocuk isnad ettiler, Allah'ın en değerli varlıkları olan melekleri kızları olarak Allah'a nispet ettiler ve son olarak ise iki türden (erkek-kız) en değersiz olanını (ehseü'n-nev'ayn) Allah'a nispet ettiler. ${ }^{12}$ Zemahşerî bu açıklamalar arasında başka bir âyete referans vermekte ve bizi söz konusu âyetin tefsirine yönlendirmektedir. Kendisi, "O, dilediğine kız, dilediğine de erkek çocuklar bahşeder."13 âyetinde şu ilginç soruyu gündeme getirmektedir: "Erkekler kadınlardan daha önde olduğu halde âyette niçin kadınlar (inâs) erkeklerden (zükûr) önce zikredilmiştir?" Verdiği cevaba göre âyet kadınlarla ilgili olduğu için önce onların zikredilmesine gerek duyulmuştur. Neyse ki âyet metninde erkekler, "ez-zükûra" şeklinde marife, kadınlar da "inâsâ" şeklinde nekre getirilmiştir. ${ }^{14}$

Müfessir İbn Atıyye (ö. 541/1147) de ilgili âyetleri tefsir ederken, "Ademoğluna evlatlardan istenileni (erkeği) Allah yaratmıştır. Nasıl olur da o daha aşağı (ednâ) olanı kendisine ayırır?" diyerek aynı çizgiyi devam ettirmektedir. Belirttiğine göre çok az kadın vardır ki konuştuğunda sözü ifsad etmesin ve manaları birbirine karıştırmasın. ${ }^{15}$

Kadını küçümseyici boyutlar kazanan bu erkek egemen yorumlar Fahreddin Râzî (ö. 606/1210) de adeta zirveye ulaşmaktadır. O seleflerinden aldığı birikime aklî istidlalleri de eklemektedir. Belirttiğine göre Allah için diyelim ki çocuk farzedilse bunun kız olması imkânsızdır.

10 Ebu'l-Muzaffer Mansur b. Muhammed es-Sem'ânî, Tefsîru'l-Kur'ân, thk. Yâsir b. İbrahim - Ganîm b. Abbas b. Ganîm (Riyad: Dâru'l-vatan, 1997), 5: 95.

11 Ebu'l-Kâsım Mahmud b. Ömer ez-Zemahşerî, el-Keşşâf an gavâmizı't-tenzîl (Beyrut: Dâru'l-Kütübi'l-Arabî, h. 1407), 4: 243.

12 Zemahşerî, el-Keşşâf, 4: 44.

13 eş-Şûrâ, $42 / 49$.

14 Zemahşerî, el-Keşşâf, 4: 232.

15 Ebû Muhammed Abdülhak b. Galib el-Endelûsî İbn Atıyye, el-Muharraru'lvecîz fi tefsîri'l-kitâbi'l-azîz, thk. Abdüsselam Abdüşşafi Muhammed (Beyrut: Dâru'l-kütübi'l-ilmiyye, h. 1422), 5: 49. 
R. O. ÖZEL / A Male-Dominant Interpretation and Evaluation in Tafsir: Review in the Context of az-Zukhruf 43/18 of the Quran I 61

Çünkü oğlan kızdan daha efdaldir. Farz-1 muhal denilse ki, "Allah kendisine kızları ayırdı, erkekleri de kullara bıraktı", kulun hali Allah'ın halinden daha üstün ve daha kâmil olur. Bu da aklen/bedîhî olarak kabul edilemez. ${ }^{16}$ Ona göre Allah ez-Zuhruf 43/18 âyet-i kerimede değişik yönlerden kadınların noksanlığına dikkat çekmektedir. Süs püs içinde büyütülen bizzat nâkıstır. Çünkü zâtı itibarıyla noksan olmasaydı, kendini süsle tezyin etmeye ihtiyaç duymazdı. İkinci olarak dilinin zafiyeti, akılsızlığı ve ahmak tabiatı nedeniyle kadın, tartışmada meramını ifade edemez. ${ }^{17}$

Osmanlı müfessiri Ebu's-Suûd Efendi (ö. 982/1524) de kadının kendi işini üstlenmekten aciz olduğunu belirtir ve Mekke müşriklerinin, kulların en mükemmel ve en mükerremi olan meleklerin rey bakımından erkeklerden daha nakıs ve sınıfça daha aşağıdaki kızlar olduğuna hükmettiklerini söylemektedir. ${ }^{18}$

Bunlardan başka Kurtubî (ö. 671/1273), Beyzâvî (ö. 685/1286), Nesefî (ö. 710/1310), İbn Cüzey (ö. 741/1340), Ebû Hayyân (ö. 745/1344), İbn Kesîr (ö. 774/1373) gibi belli başlı müfessirler de benzeri görüşleri benimsemişlerdir. ${ }^{19}$

16 Ebû Abdillâh (Ebü'l-Fazl) Fahruddîn Muhammed b. Ömer b. Hüseyn erRâzî, Mefâtîhu'l-ğayb (Beyrut: Dâru ihyâi't-türâsi'l-Arabî, h. 1420), 27: 64.

17 Râzî, Mefâtîhu'l-ğgayb, 27: 424.

18 Ebu's-suûd Muhammed b. Muhammed el-İmâdî, İrşâdü'l-akli's-selîm ilâ mezâya'l-Kur'âni'l-kerîm (Beyrut: Dâru ihyâi't-türâsi'l-Arabî, ts.), 8: 42.

19 Ebû Abdillâh Muhammed b. Ahmed b. Ebî Bekr b. Ferh el-Kurtubî, el-Câmi' li ahkâmi'l-Kur'ân, thk. Ahmed el-Berdûnî-İbrahim Itfiyiş (Kâhire: Dâru'lkütübi'l-misriyye, 1964), 16: 72; Ebû Muhammed Abdullah b. Ömer b. Muhammed el-Beyzâvî, Envâr'u't-tenzîl ve esrâru't-te'vîl, thk. Muhammed Abdurrahman el-Mer'aşlî (Beyrut: Dâru ihyâi't-türâsi'l-Arabî, h. 1418), 5: 88; Ebü'l-Berekât Hâfızüddîn Abdullah b. Ahmed b. Mahmûd en-Nesefî, Medârikü't-tenzîl ve hakâiku't-te'vîl, thk. Yusuf Ali Bedîvî (Beyrut: Dâru'lkelimi't-tayyib, 1998), 3: 268; Ebü'l-Kāsım Muhammed b. Ahmed b. Muhammed el-Kelbî el-Girnâtî İbn Cüzey, et-Teshîl li ulûmi't-tenzîl, thk. Abdullah el-Hâlidî (Beyrut: Şeriketü Dâri'l-Erkam b. el-Erkam, h. 1416), 2: 256; Ebû Hayyân Muhammed b. Yûsuf b. Alî b. Yûsuf b. Hayyân el-Endelûsî, el-Bahru'l-muhît, thk. Sidki Muhammed Cemil (Beyrut: Dâru'l-fikr, h. 1420), 9: 362; Ebü'l-Fidâ' İmâdüddîn İsmâîl b. Şihâbiddîn Ömer b. Kesîr, Tefsîru'lKur'âni'l-azîm, thk. Sâmî b. Muhammed Selâme (Riyad: Dâru taybe linneşr ve't-tevzi, 1998), 7: 223. 
62 | R. O. ÖZEL / Tefsirde Erkek Egemen Bir Yorum ve Değerlendirmesi: ez-Zuhruf 43/18 Âyet-i Kerîmesi Bağlamında Bir İnceleme

Bütün bu yorumlar arasında konuyu erkeklerde süslenmenin hükmü ile ilişkilendiren müfessirlerimiz de bulunmaktadır. Buna göre süslenmek püslenmek kadınlara ait vasıflardan olup, erkekler bu tür kusurlu ve yerilecek işlerden uzak durmalıdır. ${ }^{20}$ Allah âyet-i kerîmede süslenmeyi kusur ve noksanlığın icaplarından saydığından bu tür şeyler kadınlara mübahken erkeklere haramdır. Erkeğin süse yönelmesi kendisini zillete düşürmesi anlamına gelmektedir. Bu yüzden erkekler takva zîneti ile süslenmelidirler. ${ }^{21}$

Tefsirlerin hemen hepsine hâkim olan bu yaklaşımlara göre ezZuhruf 43/18 âyet-i kerîmedeki kadını niteleyen ifadelerin doğrudan Allah'a ait olduğu izlenimi vermektedir. Oysa O (c.c) melekleri Allah'ın kızı olarak kabul eden batıl Arap itikadını yermiştir. Ancak bu itikad yerilirken kadının süsler püsler içinde yetiştiği ve tartışma kabiliyetine sahip olmadığı şeklinde gerekçelendirmeler yapılmıştır. Böylesine aciz ve değersiz bir varlık, Allah'ın kızları olarak görülmekle inkâr içinde inkâra düşülmüştür. Böylece âyette sanki bizzat Allah'ın kadını yeren ve kadına karşı erkekten yana olan cinsiyetçi bir üslup kullandığı vehmi uyanmaktadır. Yapılan yorumlar, kızları erkek egemen anlayışla küçümseyen ve aşağılayan bir bakış açısına dönüşmüş ve dilimizdeki kadını istihfaf edici anlamlar yüklenen "saçı uzun aklı kısa" tarzı deyimleri haklı çıkarır bir mahiyet kazanmıştır.

Tefsirlerimizde genel durum bu şekildedir. Şimdi dilimizde yazılan meâllere de göz atmak ve çevirilerde tercih edilen manaların tefsirdeki mezkûr manzaranın neresine tekabül ettiğini tespit etmeye çalışacağız. Şu bir gerçek ki, meâller yazılırken önceki tefsir birikiminden yoğun bir şekilde istifade edilmektedir. Meâl yazarları çoğu kere müfessirler tarafından kaydedilen manaları dikkate almakta ve kaynaklarda yer verilen farklı yorumlardan birini tercih ederek manayı meâllerine yansitmaktadır. Durum böyle olunca müfessirlerin genel tutum ve kanaatleri meâl yazarlarının söz konusu tercihlerinde büyük ölçüde etkili olmaktadır. ez-Zuhruf 43/18 âyet-i kerîme bağlamında meâllere baktığımızda bazı istisnalar haricinde aynı durumun tekrarlandığını görmekteyiz. Tefsirlerin hemen hepsinde yer bulan, kadını fiziki ve mental yönden değersizleştirici yorumlar bir şekilde ilgili meâllere de

20 Zemahşerî, el-Keş̧̧âf, 4: 243.

21 Râzî, Mefâtîhu'l-ğayb, 27: 64. 
R. O. ÖZEL / A Male-Dominant Interpretation and Evaluation in Tafsir: Review in the Context of az-Zukhruf $43 / 18$ of the Quran I 63 yansımış görünmektedir. Ülkemizde bilinen belli başlı meâllerde söz konusu âyet-i kerîme dilimize şu şekilde aktarılmıştır:

“(Onlar) süs içinde yetiştirilmekte olup da kendisi mücadele (hüccetini) açıklamayan kişiyi mi (Allah'a nisbet ediyorlar?)"22

Çantay söz konusu meâle, "Buna göre kadınlık mücadelede erkeklere nispeten daha zayıftır." şeklinde bir açıklama notu eklemiştir.

"Süs içerisinde (narin bir biçimde) yetiştirilen ve tartışmada (delilini erkekler gibi) açıklayamayanı mı Allah'a isnad ediyorlar?" 23

"Haklarını savunması gerektiğinde bile delillerini ve gücünü tam olarak ortaya koyamaz durumda olan, süs içinde yetiştirilip büyütülen birini mi O'na evlat olarak isnad ediyorlar?"24

"Süs içinde yetiştirilip savaş edemeyecek olanı $\mathrm{m}$ istemiyorlar? (Onları Allah'ın parçası mı sayıyorlar?)" 25

Meâle şu not eklenmiştir: Âyet, kadınlardaki süslenme özellikleriyle, mücadeledeki zayıflıklarına işaret etmektedir.

"Ya o zînet içinde yetiştirilecek de muhasamaya gelince beceremeyecek olanı öyle mi?" 26

"Yoksa süs içinde yetiştirilecek olup da o mücâdele halinde delilini izhar edemeyecek olanı mı? (O Rahmân'a isnat ediyorlar)."27

"Süs içinde yetiştirilmekte olup da, kendisi mücadele delilini açıklayamayan kişiyi (kızları) mi Allah'a isnad ediyorlar?"28

"Süs içinde yetiştirilip büyütülen ve iddiasını ispat edemeyen kimseyi (yaratılışça pek zayıf olan kızları) mı? (Allah'a çocuk isnad ediyorlar)." 29

22 Hasan Basri Çantay, Kur'ân-ı Hakîm ve Meâl-i Kerîm (İstanbul: Risâle, 1993) 2: 141.

23 Halil Altuntaş - Muzaffer Şahin, Kur'an-ı Kerim Meâli (Ankara: DİB Yayınları, 2010), 489.

24 Ahmet Tekin, Lügatli Tefsiri Meal (İstanbul: Kelam Yayınları, 2010), 491.

25 Ali Özek v.dğr., Kur'ân-ı Kerîm ve Açıklamalı Meâli (Ankara: Türkiye Diyanet Vakfı Yayınları, 1997), 489.

26 Elmalılı Hamdi Yazır, Hak Dini Kur'ân Dili (İstanbul: Eser, ts.) 6: 4270.

27 Ömer Nasuhi Bilmen, Kur'ân-ı Kerîm'in Türkçe Meâli Âlisi ve Tefsiri (İstanbul: Bilmen Basım ve Yayınevi, ts.), 7: 3268.

28 Ziya Kazıcı - Necip Taylan, Kur'ân-ı Kerîm Meâli (İstanbul: Çağrı Yayınları, 1999), 255.

29 A. Fikri Yavuz, Kur'ân-ı Kerîm ve Meâl-i Âlîsi (İstanbul: Doğan Matbaacılık, 1977), 491. 
64 | R. O. ÖZEL / Tefsirde Erkek Egemen Bir Yorum ve Değerlendirmesi: ez-Zuhruf 43/18 Âyet-i Kerîmesi Bağlamında Bir İnceleme

"Yoksa onlar süs içine yetiştirilip mücadelede açık olmayanı mı (kendisini savunamayan kız çocuklarını mı) Allah'a yakıştırıyorlar?"30

Görüldüğü üzere bu meâllerde süs püs içerisinde büyütülme, delil getirmekten yoksun olma, iddiasını ispat edememe ve tartışma (muhâsama) becerisinden yoksunluk gibi yetersizlikler kadının bir özelliği olarak meâllere yansımış durumdadır. ${ }^{31}$ Müfessirlerin çoğunun benimsediği erkek egemen ve cinsiyetçi yorumlara dayanan bu meâllerin zihinlerde bazı problem ve tereddütlere yol açması kaçınılmaz olmaktadır. Söz konusu âyet-i kerime meâlleri okunduğunda -kadın ve erkeğin kendine özgü özellikleri olmakla beraber- Allah'ın kadını adeta cinsiyetçi bir bakışla değerlendirdiği gibi bir durum ortaya çıkmaktadır. Meâlde oluşan bu algı tıpkı erkekler gibi aynı kitabı okuyup anlamakla görevli kadın için pek anlaşılır gelemeyeceği gibi onların iç dünyalarında incinmesine neden olabilme ihtimali vardır. Özellikle çağımızdaki kutsal karşıtı fikri cereyanların kaynaklarımızdaki bu tür zaaflarla malul açılama ve değerlendirmeleri istismar ettiği ve edebileceği unutulmamalıdır.

Kadını ötekileştiren anlayış ve telakkiler Müslüman coğrafyaya özgü bir durum değildir. En eski çağlardan beri doğudan batıya birçok toplumda şu ya da bu şekilde olumsuz kadın algısına rastlanılmaktadır. Bu nedenle söz konusu yaklaşımların kaynağını Kur'ân ve sünnet gibi temel İslam kaynaklarında değil kültürler arası etkileşimde görmek doğru olur. ${ }^{32}$ Bize göre müfessirlerimiz söz konusu yorumlarında kendi dönemlerinde hâkim olan erkek egemen iklimin etkisinde kalmışlardır. Dolayısıyla yorumları da Tâbiîn müfessiri Katâde'den itibaren hep bu istikamette ilerlemiştir. Hemen hemen bütün müfessirlerin içinde

30 Sadreddin Gümüş v.dğr., Kur'ân-ı Kerîm ve Yüce Meâli (İstanbul: Ravza Yayınlar1, 2004), 491.

31 İlgili âyet-i kerimede geçen "الخِحَصَامِ kelimesi, h-s-m fiil kökünden müfâale babında masdar formundadır. Bir kimse cedelci olduğunda onun için " رجل ")

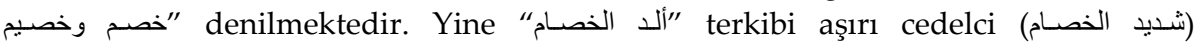
anlamına gelmektedir. "خاصمه وخصم" ifadeleri ise ona delil ve hüccetle galebe çaldı anlamina gelmektedir. Ebû Bekr Muhammed b. el-Hasen el-Ezdî, "h-sm”, Cemheretü'l-lüğa (Beyrut: Dâru'l-ilmi li'l-melâyîn, 1987), I: 605; Ebu'l-Fazl Cemâleddin b. Manzûr, "h-s-m”, Lisânü'l-Arab (Beyrut: Dâru Sâdır, 1414), 12: 180.

32 Ali Osman Ateş, Hadis Temelli Kalıp Yargılarda Kadın (İstanbul: Beyan Yayınları, 2015), 221. 
R. O. ÖZEL / A Male-Dominant Interpretation and Evaluation in Tafsir: Review in the Context of az-Zukhruf 43/18 of the Quran I 65

yetiştiği çevresel şart ve kanaatlerin adeta bir fanus gibi düşünce dünyalarını kuşattığını görmekteyiz. Ortaya çıkan bu tablo bizim için aynı zamanda tefsir ameliyesinin insanî temayüllerle nasıl iç içe girdiğinin de bir göstergesidir. Bu yorumlar tefsirlerimizde yer bulurken çoğu müfessir gerek Kur'ân'da gerekse sünnette kadına verilen değere ilişkin hiçbir veriye temas etmemiştir. Oysaki gerek Kur'ân'da gerekse tefsir mirasımızda kadına verilen değeri ortaya koyan çokca örnek bulunmaktadır. Örneğin kadını tam bir acz ve yetersizlik içerisinde değerlendiren yorumların, "Allah katında sizin en değerliniz en takvâlı olanınızdır", "Biz insanı en mükemmel şekilde yarattık" gibi ırkı, cinsiyeti, nesebi, zenginliği ve her türlü dünyevi rütbeyi geride bırakan âyetlerle bağdaşıp bağdaşmadı̆̆ına hiç mi hiç işaret edilmemiştir. Yine Havle bnt. Sa'lebe'nin kocasını Hz. Peygambere şikâyet ederken kullandığı etkili ve dokunaklı ifadelerini yine aynı tefsirlerimiz nakletmektedir. ${ }^{33}$ Firavun'un mümin hanımı ile Hz. Meryem de Kur'ân tarafından örnek hanım şahsiyetler olarak gösterilmektedir. ${ }^{34}$

Görebildiğimiz kadarıyla bu konudaki istisnai yorumlardan birisi Rûhu'l-Beyân adlı tefsirin sahibi İsmail Hakkı Bursevi'ye (ö. 1137/1725) aittir. Bursevî, kadının sözü edilen vasıflarının genel duruma göre olduğunu, yoksa kadınlar arasında erkeklerden daha fasih ve daha üstün kimselerin de olduğunu dile getirmektedir. Ardından kendisi $\mathrm{Hz}$. Aişe'nin fesâhatı, zekâsı ve anlayışı üzerine bazı notlar nakletmektedir. ${ }^{35}$ Bununla beraber bahsi geçen noksanlıkların kadınların genel evsafı olduğunu söylemekten de kendisini alamamakta zekâ ve anlayış gibi özellikleri kadın söz konusu olduğunda istisnai durumlar olarak görmektedir.

Şüphesiz Allah'a evlad isnad etmek cinsiyet üzerinden değerlendirilemeyecek büyük bir günahtır. Yani biz Allah'ın kendisine kız çocuk isnad edilmesini daha büyük bir günah olarak gördüğü kanaatinde değiliz. Bu günahın cinsiyete göre bir değerlendirmeye konu olması da mümkün değildir. Nitekim Kur'ân yeri geldiğinde Allah'a oğul isnad eden Hıristiyanları da Yahudileri de ağır bir dil ve üslupla reddetmiştir. Dolayısıyla Allah'a çocuk isnadını erkek ve kız üzerinden değerlendirme yoluna gitmek isabetli bir yaklaşım olmasa gerektir.

33 İbn Kesîr, Tefsîru'l-Kur'âni'l-azîm, 8: 34.

34 et-Tahrîm, 66/11.

35 İsmail Hakkı Bursevi, Rûhu'l-beyân (Beyrut: Dâru'l-fikr, ts.), 8: 358. 
66 | R. O. ÖZEL / Tefsirde Erkek Egemen Bir Yorum ve Değerlendirmesi: ez-Zuhruf 43/18 Âyet-i Kerîmesi Bağlamında Bir İnceleme

\section{2. İbn Zeyd'in "Putlar" Yorumu}

ez-Zuhruf 43/18 âyet-i kerîmede ikinci yorum İbn Zeyd'e aittir.

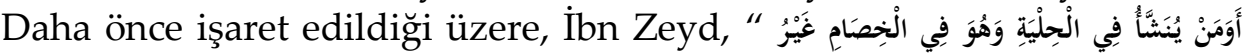
"مِبِين âyetindeki ism-i mevsulden kastedilenlerin putlar olduğu kanaatindedir. Buna göre müşrik Araplar, tapınmak için yaptıkları timsalleri altın ve gümüş ile tezyin etmişlerdir. Âyetin son kısmındaki "غَيَرْ مُعِينٍ ifadesi ise putların konuşmaktan aciz oluşunu ifade etmektedir. ${ }^{36}$

İbn Zeyd'in bu görüşü, müfessirlerin çoğunluğu tarafından pek itibar görmemiştir. Nitekim âyette câriye ve kadınların kastedildiği görüşünü tercihe şayan bulan Taberî, tercihini âyetin siyak-sibakı üzerinden gerekçelendirmektedir. Buna göre söz konusu ifade müşriklerin kendileri için hoş görmedikleri kızları Allah'a izâfe etmeleri haberinden hemen sonra gelmiştir. Dolayısıyla bu konudaki kelamı, siyak ve sibaka uygun olarak- kendisine benzer olan kelama tâbî kılmak, hiç zikri geçmeyen manaya tâbî kılmaktan daha evladır. ${ }^{37}$ Yine Ebû Hayyân da Taberî gibi "وَهُوَ فِي الْخِصَام غَيْرُ مُبِين ifadesine dayanarak söz konusu yorumu isabetli bulmaz. ${ }^{38}$

Bununla beraber İbn Zeyd'in benimsediği "putlar" yorumu, dikkate alınması gereken bir yaklaşımdır. Çünkü müşriklerin bazı putları/kadın kız şeklinde tasvir veya tasavvur ettikleri bilinmektedir. Nitekim Câhiliye dönemi bölge Araplarının başlıca tazimde bulundukları Lât, Menât ve Uzzâ putlarının kadın olarak kabul edildiği anlaşılmaktadır. Her üç putun da lafızda müenneslik alâmeti taşıdığ görülmektedir. Taberî'nin izahına göre Lât, Allah isminden, Uzzâ, aziz isminden müennes yapılmıştır. Ve müşrikler bunların da Allah'ın kızları olduğunu iddia etmişlerdir. ${ }^{39}$ Fahreddin Râzî, Lât kelimesindeki "te" nin

36 Taberî, Câmi'u'l-beyân, 21: 580; Ebû İshak Ahmed b. Muhammed b. İbrahim es-Sa'lebî, el-Keşf ve'l-beyân an tefsîri'l-Kur'ân, thk. Ebû Muhammed b. Âşûr (Beyrut: Dâru ihyâi't-türâsi'l-Arabî, 2002), 8: 331; Ebu'l-Hasan Ali b. Muhammed el-Maverdî, en-Nüket ve'l-uyûn, thk. Seyyid b. Abdilmaksûd b. Abdirrahim (Beyrut: Dâru'l-kütübi'l-ilmiyye, ts.), 5: 219; Kurtubî, el-Câmi' li ahkâmi'l-Kur'ân, 16: 72.

37 Taberî, Câmi'u'l-beyân, 21: 580-81.

38 Ebû Hayyân Muhammed b. Yûsuf el-Endelûsî, el-Bahru'l-muhît, thk. Sıdkı Muhammed Cemil (Beyrut: Dâru'l-fikr, h. 1420), 9: 63.

39 Taberî, Câmi'u'l-beyân, 22: 522. 

az-Zukhruf 43/18 of the Quran | 67

aslen müennes olduğunu vakıf halinde lafzatullah ile karışmaması için mushaf hattında açık olarak yazıldığını belirtmektedir. ${ }^{40}$

Burada şunu ifade etmek gerekir ki, Lât isminin sonundaki "te" harfinin açık yazılması dolayısıyla bunun müenneslik alâmeti olmadığı yönünde görüşler de bulunmaktadır. Ancak durum böyle olsa bile her üçü de Câhiliyye Arapları nezdinde müennes kabul edilmişlerdir.

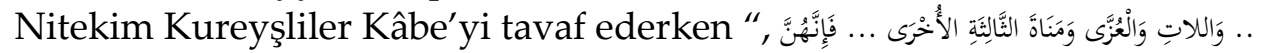
şeklinde takdiste bulunmaktaydilar. ${ }^{41}$ İbrahim Usta'nın Philip Wilkinson'dan naklettiğine göre Lât ismi ilk olarak tapınak bekçisine yakıştırılmış ve onun ölümünden sonra gömülü olduğu yeri gösteren taşa verilmiştir. Daha sonra bu taşın üstüne tanrıçanın bir büstü yerleştirilerek el-Lât tanrıçanın kendisi olarak anılmaya başlanmıştır. ${ }^{42}$

Bu yüzden müfessirlerden bazısı Necm sûresi, "Gördünüz mü Lât'1 ve Uzzâ'yı ve üçüncüleri Menât'1. Erkekler sizin de kızlar onun öyle mi...?" (en-Necm, 53/19, 20) âyetlerini izah ederken takdirde bulunarak, “Ey Lât, Menât ve Uzzâ'nın Allah'ın kızı olduğunu söyleyenler, erkekler sizin de kızlar onun mu? O zaman bu haksız bir taksim." şeklinde anlamışlardır. ${ }^{43}$ İbn Âşûr'a göre de hem Zemahşerî hem de İbn Atıyye'nin yer verdiği bu yorum âyetlerin siyak-sibakı açısından desteklenmektedir. ${ }^{44}$

Sünen-i Beyhakî muhakkiki adı geçen üç meşhur putun Allah'ın kızları olarak inandıkları meleklerin bir timsâli olarak yapıldığı görüşündedir. $\mathrm{O}$ bu görüşüne $\mathrm{Necm}$ sûresi âyetlerini delil olarak göstermektedir. ${ }^{45}$ Şu bir gerçek ki, siyer kaynaklarında nakledilen bilgiye göre, Kureyş'in önde gelenleri Efendimize gelmişler ve nübüvvet konusunda tartışmışlardı. İçlerinden birisinin kendilerinin meleklere

40 Râzî, Mefâtîhu'l-ğayb, 28: 247.

41 Ebu'l-Münzir Hişâm b. Muhammed İbn el-Kelbî, Kitâbu'l-asnâm, thk. Ahmed Zeki Paşa (Kâhire: Dâru'l-kütübi'l-Misriyye, 2000), 19.

42 İbrahim Usta, İslam Öncesi Arap Mitolojisi (Ankara: Ankara Okulu, 2019), 134.

43 Sa'lebî, Tefsîru'l-Kur'ân, 9: 146.

44 Muhammed b. et-Tâhir b. Muhammed İbn Âşûr, et-Tahrîr ve't-tenvîr (Tunus: ed-Dâru't-Tûnusiyye, 1984), 27: 103.

45 Ebû Bekr Ahmed b. el-Hüseyn b. Alî el-Beyhakī Delâilü'n-nübüvve ve ma'rifetü ahvâli sâhibi'ş-şerîa, thk. Abdülmuti Kal'acî (Mukaddime) (Beyrut: Dâru'l-kütübi'l-ilmiyye, h. 1405), 75. 
68 | R. O. ÖZEL / Tefsirde Erkek Egemen Bir Yorum ve Değerlendirmesi: ez-Zuhruf 43/18 Âyet-i Kerîmesi Bağlamında Bir İnceleme

taptıkları ve onların Allah'ın kızları olduğunu söylediği nakledilmektedir. ${ }^{46}$ Ancak kaynaklarda bu putların meleklerin timsâli olduğuna dair açık ve net bilgilere rastlamış değiliz. Yine de siyak-sibak açısından Necm sûresi âyetlerinde büyük tazim gören üç putun kadın olarak tasvir edildiklerine dair ima ve işaret yok değildir. Nitekim İsmail Cerrahoğlu da "Meleklerin Allah'ın kızları olduğuna inanan Kureyşliler'in, putlarını genç ve güzel kızlara benzetmiş olmaları da mümkündür." 47 demektedir.

Bütün bu izahlardan sonra ez-Zuhruf 43/18 âyetindeki "men" ism-i mevsulünün $\mathrm{klz}$ olarak telakki edilen putlarla ilgili olduğu

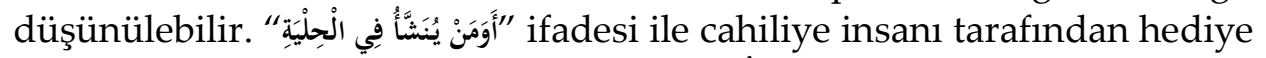

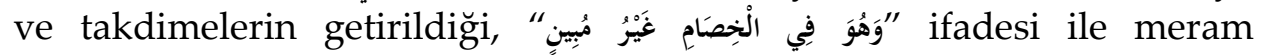
anlatmaktan aciz olan ve müennes olarak tasavvur veya tasvir edilen putlar kastedilmiş olabilir. İlgili ism-i mevsulden kastedilen dişil kabul edilen putlarsa bu yoruma engel teşkil ettiği ifade edilen siyak-sibak problemi de büyük ölçüde ortadan kalkmış olmaktadır. Şu halde ilgili âyet-i kerime öncesi ve sonrası ile bir yandan kız çocuğunu istemezken diğer yandan da "süslenip bezenen ve kendini savunmaktan aciz olanları (tanrıçaları) mı Allah'a isnad ediyorsunuz." şeklinde anlaşılır.

\section{Tercih Ettiğimiz Yorum}

İbn Zeyd'in tercihini yukardaki gibi izah edebilsek de biz burada üçüncü bir yorumun daha mümkün olduğunu ve bunun daha isabetli

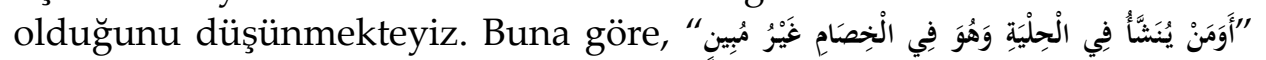
ifadesindeki "مَنْ" ism-i mevsulü ile "kadın"a işaret edilmektedir. Dil

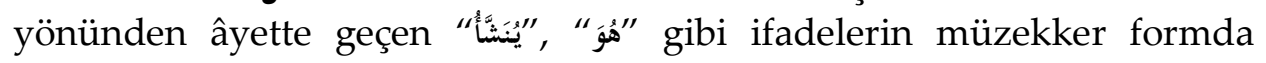
kullanılması bu manaya engel değildir. Çünkü hem müzekker hem müennes için kullanılabilen "men" ism-i mevsulünün kadına delalet etmesine rağmen lafzına itibarla şeklen müzekker gibi kabul gördüğü

46 Ebû Muhammed Cemâlüddîn Abdülmelik b. Hişâm, es-Sîratü'n-nebeviyye, thk. Taha Abdurraûf Sad (b.y.: Şeriketü et-tıbâati'l-fenniyyeti'l-müttehıde, ts.), 1: 263, Ebû Abdillâh Muhammed b. İshak, Sîretü İbn İshâk, thk. Süheyl Zükâr (Beyrut: Dâru'l-fikr, 1978), 199.

47 İsmail Cerrahoğlu, "Garânik", Türkiye Diyanet Vakfi İslam Ansiklopedisi (Ankara: TDV Yayınları, 1996), 3: 364. 
R. O. ÖZEL / A Male-Dominant Interpretation and Evaluation in Tafsir: Review in the Context of az-Zukhruf 43/18 of the Quran | 69

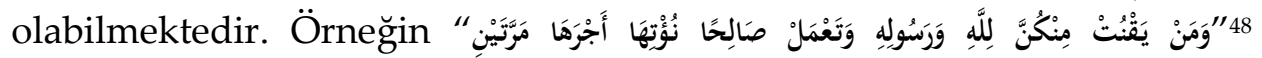
âyetinde böyle bir durum söz konusudur. ${ }^{49}$

Ancak bu manayı cinsiyetçi boyutlara varan yorumlara mesned yapılacak şekilde ilahi bir tespit olarak değil, câhiliye insanının sosyal ve kültürel dünyasındaki "kadın" algısı ile ilişkilendirerek bir açıklama getirmek daha isabetli olacaktır. Bunun için hem tarihî ve hem Kur'ânî açıdan konuya ilişkin veriler bu yaklaşımı yeterince destekler niteliktedir. Zira dünyanın pek çok yerinde olduğu gibi erkek egemen anlayışın ileri derecede hüküm sürdüğü câhiliye devrinde kadının ötekileştirildiği hatta varoluşsal anlamda oldukça geri plana atıldığı bilinmektedir. Câhiliye aklı, kız çocuğunu taşınması ağır bir yük olarak görmekteydi. Maddi imkânsızlık ve yoksulluğun kızın ahlakını kötüleştireceği, ar perdesini yırtacağı düşüncesi söz konusuydu. ${ }^{50}$ Kabileler arası mücadele ve savaşlar akabinde esarete götürülen kadınlar yakınları için zillet ve utanç vesilesi idi. Buna karşın erkek çocuk cahiliye toplumunun iktisâdî ve ictimâî hayatında önemli bir unsur olmuştur. Babaya, ailesine ve akrabasina harplerde destek oluyordu. Onun esir olması kadınların esareti gibi kötü karşılanmıyordu. Savaşa kadir olamayan kadin ise düşmana av oluyordu. ${ }^{51}$

Bu telakkilere bağlı olarak çocuğ u kız olduğu için bir travma hali yaşayan ve evini terk edenlere rastlandığı görülmektedir. Bir Arap kadını kız çocuğu dünyaya getirdiği için eşi tarafından terkedildiğinde duygularını şu şekilde ifade etmektedir:52

$$
\text { غا لأبي حمزة لا يأتينا ... يظل في البيت الذي يلينا؟ }
$$

Ebû Hamza'ya ne oldu da bize gelmiyor!... Bizim evden sonraki evde kalmaya devam ediyor!"

Erkek çocuklar doğurmadım diye bize öfkelenir

(Rab) Bize ne bahşederse ancak onu alırız

48 el-Ahzâb, 33/31.

49 Ebu'l-Hasen Ali b. İsmail b. Sîde el-Mürsî, el-Muhassas, thk. Halil İbrahim Ceffâl (Beyrut: Dâru ihyâi't-türâsi'l-Arabî, 1996) 7: 180.

50 Abdullah Afîfî, el-Mer'etü'l-arabiyyetü fî câhiliyyetihâ ve İslâmihâ (Medîne: Mektebetü's-sekâfe, 1933), 1: 44.

51 Cevad Ali, el-Mufassal fî̀ târîhi'l-Arab kable'l-İslâm (Beyrut: Dâru's-sâkî, 2001), 9: 96.

52 Zemahşerî, el-Keşşâf, 4: 243. 
70 | R. O. ÖZEL / Tefsirde Erkek Egemen Bir Yorum ve Değerlendirmesi: ez-Zuhruf 43/18 Âyet-i Kerîmesi Bağlamında Bir İnceleme

Böylece kimi Araplar kız çocuğuna istemeye istemeye bakmak zorunda kalmakla diri diri toprağa gömmek arasında ikilem yaşamaktayd1. ${ }^{53}$ Kur'ân-1 Kerîm bu duruma açıkça işaret etmektedir.

Câhiliye toplumunda çokça öne çıkmasa da dini sâiklerle k1z çocuklarının hayatlarına son verdikleri de belirtilmiştir. Buna göre meleklerin Allah'ın kızları olduğuna inanan Huzâa ve Kinâne kabileleri,

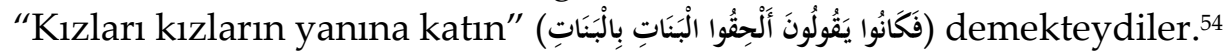

Fahreddin Râzî, cahiliyedeki sosyal telakkinin marazî psikolojiye dönüşüne değinirken doğan kız çocuklarından farklı şekillerde de kurtulmaya çalıştıklarını, yüksek bir dağ yamacından atma, suda boğma hatta kesme gibi yöntemler kullandıklarını söylemektedir. ${ }^{55}$

$\mathrm{Bu}$ durumda neden erkeğin değil de kız çocuğunun ölüme mahkûm edildiği düşünülebilir. Fiziksel güce dayalı işlerin revaçta olması hasebiyle erkeğin aynı zamanda ekonomik güç olarak değerlendirildiği, yine erkek çocuklarının aile ve soy için savunma ve taarruz gücüne sahip olma anlamına geldiği düşünülebilir. Nitekim miras âyetleri ile kadına da mirastan pay veren hükümler nâzil olduğunda bir kısım insanların gösterdiği tepkiler bu zihin dünyasının bir yansıması olarak belirmiştir. Nitekim âyetler kadınlara mirastan pay verince bazıları "Ata binip düşmanla savaşmayan, ganimet alamayan kadınlara mı miras verilecek?" 56 şeklinde konuşmuşlardır. Bu yüzden Arap yarımadası toplumlarında erkeklere çok ihtiyaç olduğu düşüncesi hakimdi. ${ }^{57}$

Kur'ân bu alg1 ve düşünceye işaret etmekte erkek çocukların çokluğunun toplumda bir güç gösterisine dönüştügüne değinmektedir. Bu kapsamda ekonomik güç ve paranın erkek çocuklarla yan yana anıldığ 1 ve asıl kalıcı olan şeylerin yani sâlih amellerin vurgulandığı görülmektedir. ${ }^{58}$ Yine bir başka âyet-i kerimede "O gün kalb-i selimle gelen hariç kimseye mal ve oğullar fayda vermez" ${ }^{59}$ denilmektedir.

\footnotetext{
53 Abdullah Afîfî, el-Mer'etü'l-arabiyyetü fî câhiliyyetihâ ve İslâmihâ, 2: 16.

54 Kurtubî, el-Câmi' li ahkâmil'l-Kur'ân, 10: 116.

55 Râzî, Mefâtîhu'l-ğayb, 20: 226.

56 Taberî, Câmi'u'l-beyân, 8: 72.

57 Murat Sarıc1k, Put (İstanbul: Nesil Yayınları, 2014), 93.

58 el-Kehf, 18/46.

59 eş-Şuarâ, 26/88, 89.
} 
R. O. ÖZEL / A Male-Dominant Interpretation and Evaluation in Tafsir: Review in the Context of az-Zukhruf 43/18 of the Quran I 71

İşte iktisâdî, ictimâî ve belki dini birtakım sebeplere dayalı olarak ortaya çıkan ve kadını istenmedik bir varlık konumuna indiren anlayış Kur'ân tarafından reddedilmiştir. Hayatına son verilen masum çocukların hesabının ahirette sorulacağı bildirilmiştir. ez-Zuhruf 43/18 âyetinde öncelikle bu algiya temas edilmektedir.

Diğer taraftan cahiliye anlayışının kadını aşağılayıcı bir telakkiye sahip olduğu anlaşılmaktadır. Bu bağlamda kadının, süs püs işiyle meşgul olan, iki laf edemeyen ve kendini sözlü olarak savunmaktan aciz kalan bir varlık şekilde kabul edildiğini anlıyoruz. Tam da burada Kur'ân cahiliye Arabının bir çelişkisini yüzlerine vurmakta ve bunun üzerinden batıl itikatlarını reddetmektedir. Kadını kendi dünyalarında son derece değersizleştiren hatta aşağılayan bu insanlar bir yandan da melekleri Allah'ın kızları olarak tasavvur etmişlerdir. Dolayısıyla cinsiyeti yüzünden aşağılanan, istenmeyip dişlanan hatta katledilen bir varlığın Allah'a nispet edilmesi kendi içinde büyük bir tezat oluşturmaktadır. Nitekim "Size erkekleri tahsis etti de kendisi meleklerden kızlar mı edindi?" (el-İsrâ, 17/40), “...Eğer öyleyse bu adil olmayan bir paylaşımdır" (en-Necm, 53/22), "Sevmediklerini Allah'a nispet ediyorlar ve dilleri yalan söylüyor" (en-Nahl, 16/57) ifadeleri bu çelişkiyi ortaya koymaktadır.

Şu bir gerçek ki, Allah kız olsun erkek olsun çocuk edinmekten münezzehtir. Onlar melekleri Allah'ın kızları olarak görme yerine kendi değer verdikleri erkek cinsini Allah'a isnad etmiş olsalard1 yine bozuk bir itikada sahip olacaklardı. Dolayısıyla burada sorun mutlak surette kız cinsinin Allah'a isnadı değildir. Ancak yukarıda da görüldüğü üzere tefsirlerin büyük kısmı ilgili âyeti bu zeminde ele almışlar ve sanki cahiliye insanının kadın telakkisini zımnen tasdik edici açılamalar yapmışlardır. Oysaki ez-Zuhruf 43/18 âyetini de itikatlarındaki tezatlık üzerinden açıklamak isabetli olacaktır. Zira onlar aşağıladıkları kadın cinsini Allah'a isnad etmekte beis görmemektedirler.

Kur'ân bu bozuk ve kendi içinde çelişkiler taşıyan itikadı reddederken kız çocukları ile ilgili telakkiyi de ayrıca kınamakta ve reddetmektedir.

“Onlardan birine kız müjdelense, gam keder içinde yüzü simsiyah kesilir. Kötü müjdeden dolayı insanlardan saklanır. Onu utanç içinde tutsun mu yoksa toprağa mı gömsün? Ne kötü hüküm veriyorlar." (enNahl, 16/58-59) 
72 I R. O. ÖZEL / Tefsirde Erkek Egemen Bir Yorum ve Değerlendirmesi: ez-Zuhruf 43/18 Âyet-i Kerîmesi Bağlamında Bir İnceleme

Şu halde Allah'ın kızlar söz konusu olduğunda onları aşağılayıcı bir dil kullanması söz konusu değildir. Bu durumda ilgili âyet-i kerîmeyi hem bu açıklamalar hem de siyak-sibak doğrultusunda takdirde bulunarak meâllendirmek yerinde olacaktır. Bu durumda iki ihtimal ortaya çıkmaktadır. Bir ihtimale göre söz konusu âyet-i kerîme, cahiliyye Arabının kız çocuğu olduğunda verdiği tepki ve sözlerini tahkiye etmektir. Buna göre mana şu şekilde verilebilir:

"Yoksa Allah kendisine k1zlar edindi de size de erkekleri mi tahsis etti? Onlardan biri, Rahman'a isnad ettiği kı çocuğu ile müjdelendiğinde gam keder içinde yüzü simsiyah kesilir. Vah, süs püs içinde büyütülen ve çekişmede kendisini açıkça ifade edemeyen mi! (diyerek hayıflanır/isyan eder)" (ez-Zuhruf 43/16-18)

Bir diğer ihtimale göre ise söz konusu ifade cahiliye anlayışını ilzam edici olarak Allah'ın yönelttiği bir sualdir. Bu durumda da mana, "(Anlayışınıza göre) süs püs içinde büyütülen ve kendini savunamayanı mi (Allah'a isnad ediyorsunuz?)"

$\mathrm{Bu}$ durumda şu meâlleri de isabetli yorumlar kapsamında değerlendirmemiz mümkündür:

“Mücadelede başarısız olarak ömrünü süslenmekle geçirecek olan kız çocuğu mu?" diye öfkeyle sorar." 60

"Öyle ya, "(para harcanıp) süs püs içinde yetiştirilecek ve savaşta hiçbir işe yaramayacak biri" söz konusudur." 61

"Ardından, "Demek şimdi ben, süs-püs içinde büyüyecek, büyüdüğü zaman da kendini savunmaktan bile aciz olacak bir kız çocuk sahibi oldum!" diye söylenir durur."62

\section{Sonuç}

Tefsir ameliyesi müfesssirin bilgi, birikim ve kültürel düzeyi ile sıkı bir ilişkisi olan ictihadi bir eylemdir. Bu yönüyle söz konusu yorumların sürekli vahyin gözetiminde olan Kur'ân'ın ilk ve tartışmasız mübelliğ ve müfessiri Hz. Peygamberin açıklamaları ile aynı düzeyde olması beklenemez. Tefsir usûl ve kâideleri tefsiri keyfi bir faaliyet olmaktan

60 Hayrettin Karaman v.dğr., Kur'an-ı Kerim ve Meâli (Ankara: DİB Yayınları, 2015), 489.

61 Murat Sülün, Kur'an-ı Kerim ve Türkçe Anlamı (İstanbul: Çağrı Yayınları, 2012), 490.

62 Mustafa Öztürk, Kur'an-ı Kerim Meali (Ankara: Ankara Okulu Yayınları, 2016), 667. 

az-Zukhruf 43/18 of the Quran I 73

çıkarsa da her müfessirin açıklamalarında az ya da çok kendi tarih ve kültürünün etkisinde kalması kaçınılmazdır. Tespitimize göre bu olgunun tipik örneklerinden biri ez-Zuhruf 43/18 âyet-i kerimesine getirilen izahlardır. Bu âyetin tefsirinde başlıca iki görüş söz konusu olmuştur. Bir görüş âyette geçen "men” ism-i mevsulünü kadın olarak yorumlarken diğer görüş putlara hamletmiştir. Bununla beraber birinci görüş üzerine bina edilen yorumlar genel kabul görmüştür. Ancak tefsir tarihinde bilinen hemen hemen bütün temel kaynaklarda ilgili âyet-i kerîme erkek egemen yorumlara sahne olmuş hatta yer yer cinsiyetçi yaklaşımlara dönüşmüştür. Öyle ki bu yorumlar okunduğunda kadın aklının süslenmekten öteye geçmediği, düşüncelerini düzenli bir şekilde ifade etmekten ve bir başkası ile aciz olduğu, cinsiyet bakımından erkeğe göre daha değersiz olduğu gibi hususların öne çıkarıldı̆̆ı görülmektedir. Buna göre böylesine nâkıs vasıfları hâiz bir varlığın Allah'ın kızı olmasının mümkün olmadığı vurgulanmaktadır. Tefsirlerin bu genel tavrının bazı meâllere de yansıdı ğı görülmüştür. İşin daha da problemli olan yönü ise Allah'ın kadını bu olumsuz sıfatlarla tavsif ettiği şeklinde bir tablonun ortaya çıkmasıdır. Oysa ki Allah'a oğul isnad etmenin ağırlığı O'na kız isnad etmeninkinden daha hafif değildir. Bu konuda Kur'ân'da Hz. İsa'yı Allah'ın oğlu olarak niteleyen Hristiyanlar'a yöneltilen ağır tenkitleri okumak yeterlidir. Bize göre ez-Zuhruf 43/18 âyet-i kerimesi câhiliye aklının bir tasvirinden ibarettir. Söz konusu âyeti kerîme, melekleri Allah'ın kızları olarak niteleyerek Allah'a çocuk isnad eden câhiliye anlayışını yermek ve kendi mantaliteleri açısından bir çelişkiyi ortaya koymak üzere gelmiştir. Başka pek çok âyetin de delâletiyle Kur'ân, kız çocuğu olduğu için dünyası kararan insanın ruh haline bürünen, utancından insanlardan kaçacak yer arayan hatta öz kızını diri diri gömmek gibi bir cinayet işleyen câhiliye aklını ilzâm etmektedir. Kendi dünyalarında bu kadar nefret duydukları kız cinsiyetini Allah'a isnad etmekte beis görmemektedirler. Kur'ân onların çelişkilerini yüzlerine vurmak suretiyle itikadlarının yanlışlığını ortaya koymaktadır. Bunu kör bir taklitle batıl inançları sürdürenleri düşünmeye sevk etmek veya ezberlerini bozmak gibi bir gayeye matuf olarak görmek mümkündür. Bu hitaba kulak verecek bir câhiliye insanın hem kız çocuğundan olabildiğince nefret etme hem de melekleri Allah'ın kızları olarak görme şeklindeki çelişkisini görmesini sağlamaktır. İkinci bir ihtimal olarak da kız çocuğu ile müjdelenen câhiliye Arabının içinden 
74 | R. O. ÖZEL / Tefsirde Erkek Egemen Bir Yorum ve Değerlendirmesi: ez-Zuhruf 43/18 Âyet-i Kerîmesi Bağlamında Bir İnceleme

geçirdiği düşünce ve hayıflanma halinin betimlenmesinden ibarettir. Âyetlerin siyâk sibâkı bu düzlemdeki yorumlarla mutabakat arzettiği gibi değer ve üstünlüğü iman ve takvaya bağlayan, kadın ya da erkek insan türünü en güzel şekilde yarattığını ifade eden, kimi kadın şahsiyetleri numûne-i imtisal olarak gösteren diğer Kur'ân âyetleri ile uyumludur. Kadınla ilgili söz konusu olumsuz yorumları tasvip etmek mümkün değildir. İlgili yorumu destekleyecek herhangi bir hadis-i şerif de söz konusu değildir. Bize göre müfessirlerin ilgili yaklaşımları gerek batı ve gerekse doğu toplumlarına hâkim olan erkek egemen telakkilerden ileri gelmektedir.

\section{Kaynakça}

Afîfî, Abdullah. el-Mer'etü'l-arabiyyetü fì câhiliyyetihâ ve İslâmihâ. Medîne: Mektebetü's-sekâfe, 1933.

Altuntaş Halil - Şahin, Muzaffer. Kur'an-ı Kerim Meâli. Ankara: DİB Yayınları, 2010.

Ateş, Ali Osman. Hadis Temelli Kalıp Yargılarda Kadın. İstanbul: Beyan, 2015.

Beyhakî, Ahmed b. el-Huseyn b. Ali. Delâilü'n-nübüvve ve ma'rifetü ahvâli sâhibi'ş-şerîa. Thk. Abdülmuti Kal'acî. 7 Cilt. Beyrut: Dâru'lkütübi'l-ilmiyye, h. 1405.

Beyzâvî, Ebû Muhammed Abdullah b. Ömer b. Muhammed. Envâr'u'ttenzîl ve esrâru't-te'vîl. Thk. Muhammed Abdurrahman el-Mer'aşlî. 5 Cilt. Beyrut: Dâru ihyâi' t-türâsi'l-Arabî, h. 1418.

Bilmen, Ömer Nasuhi. Büyük Tefsir Tarihi ve Tabakâtü'l-müfessirîn. 2 Cilt. İstanbul: Bilmen Yayınevi, 1973.

Bilmen, Ömer Nasuhi. Kur'ân-ı Kerîm'in Türkçe Meâli Âlisi ve Tefsiri. 8 Cilt. İstanbul: Bilmen Basım ve Yayınevi, ts.

Bursevî, İsmail Hakkı. Rûhu'l-beyân. 10 Cilt. Beyrut: Dâru'l-fikr, ts.

Cerrahoğlu, İsmail. "Garânîk". Türkiye Diyanet Vakfi İslam Ansiklopedisi. 13: 361-366. Ankara: TDV Yayınları, 1996.

Cevad Ali. el-Mufassal fî târîhi'l-Arab kable'l-İslâm. 20 Cilt. Dâru'ssâkî, 2001.

Çantay, Hasan Basri. Kur'ân-ı Hakîm ve Meâl-i Kerîm. 3 Cilt. İstanbul: Risâle, 1993.

Dâvûdî, Şemseddin Muhammed b. Ali Ahmed. Tabakâtü'l-müfessirîn. Beyrut: Dâru'l-kütübi'l-ilmiyye, 2002. 
R. O. ÖZEL / A Male-Dominant Interpretation and Evaluation in Tafsir: Review in the Context of az-Zukhruf 43/18 of the Quran I 75

Ednevî, Ahmed b. Muhammed. Tabakâtü'l-müfessirîn. Thk. Süleyman b. Salih el-Hazzî. Suûd: Mektebetü'l-ulûm ve'l-hikem, 1997.

Endelûsî, Ebû Hayyân Muhammed b. Yûsuf. el-Bahru'l-muhît. Thk. S1dk1 Muhammed Cemil. 10 Cilt. Beyrut: Dâru'l-fikr, h. 1420.

Ezdî, Ebû Bekr Muhammed b. el-Hasen. Cemheretü'l-lüğa. 3 Cilt. Beyrut: Dâru'l-ilmi li'l-melâyîn, 1987.

Gümüş, Sadreddin - Çiçek, Yakup - Demirci, Muhsin. Kur'ân-ı Kerîm ve Yüce Meâli. İstanbul: Ravza, 2004.

Taberî, Ebû Cafer Muhammed b. Cerîr. Câmi'u'l-beyân fî te'vîli'l-Kur'ân. Thk. Ahmed Muhammed Şakir. 24 Cilt. Beyrut: Müessesetü'rrisâle, 2000.

İbn Âşûr, Muhammed b. et-Tâhir b. Muhammed. et-Tahrîr ve't-tenvîr. 30 Cilt. Tunus: ed-Dâru't-Tûnusiyye, 1984.

İbn Atıyye, Ebû Muhammed Abdülhak b. Galib el-Endelûsî. elMuharraru'l-vecîz fî tefsîri'l-kitâbi'l-azîz. Thk. Abdüsselam Abdüşşafi Muhammed. 5 Cilt. Beyrut: Dâru'l-kütübi'l-ilmiyye, h. 1422.

İbn Cüzey, Ebü'l-Kāsım Muhammed b. Ahmed b. Muhammed el-Kelbî el-Girnâtî. et-Teshîl li ulûmi't-tenzîl. Thk. Abdullah el-Hâlidî. 2 Cilt. Beyrut: Şeriketü Dâri'1-Erkam b. el-Erkam, h. 1416.

İbn Hişâm, Ebû Muhammed Cemâlüddîn Abdülmelik. es-Sîretü'nnebeviyye. Thk. Taha Abdurraûf Sa'd. 2 Cilt. b.y.: Şeriketü ettıbâati'l-fenniyyeti'l-müttehıde, ts.

İbn İshak, Ebû Abdillâh Muhammed. Sîretü İbn İshâk. Thk. Süheyl Zükâr. Beyrut: Dâru'l-fikr, 1978.

İbn el-Kelbî, Ebu'l-Münzir Hişâm b. Muhammed. Kitâbu'l-asnâm. Thk. Ahmed Zeki Paşa. Kâhire: Dâru'l-kütübi'l-Misriyye, 2000.

İbn Kesîr, Ebü'l-Fidâ' İmâdüddîn İsmâîl b. Şihâbiddîn Ömer. Tefsîru'lKur'âni'l-azîm. Thk. Sâmî b. Muhammed Selâme. 8 Cilt. Riyâd: Dâru taybe linneşr ve't-tevzi, 1998.

İbn Manzûr, Ebü'l-Fazl Cemâlüddîn Muhammed b. Mükerrem. "Fsr". Lisânü'l-Arab. 5: 55. 15 Cilt. Beyrut: Dâru Sadr, h. 1414.

İbn Manzûr, Ebü'l-Fazl Cemâlüddîn Muhammed b. Mükerrem. "Hsm”. Lisânü'l-Arab. 12: 180. 15 Cilt. Beyrut: Dâru Sadr h. 1414.

İmâdî, Ebussuûd Muhammed b. Muhammed. İş̧âdü'l-akli's-selîm ilâ mezâya'l-Kur'âni'l-kerîm. 9 Cilt. Beyrut: Dâru ihyâi't-türâsi'l-Arabî, ts. 
76 | R. O. ÖZEL / Tefsirde Erkek Egemen Bir Yorum ve Değerlendirmesi: ez-Zuhruf 43/18 Âyet-i Kerîmesi Bağlamında Bir İnceleme

Karaman, Hayrettin - Çağrıcı, Mustafa - Dönmez, İbrahim Kâfî - Gümüş, Sadreddin. Kur'an-ı Kerim ve Meâli. Ankara: DİB Yayınları, 2017.

Kazıcı, Ziya - Taylan, Necip. Kur'ân-ı Kerîm Meâli. İstanbul: Çağrı Yayınları, 1999.

Kurtubî, Ebû Abdillâh Muhammed b. Ahmed b. Ebî Bekr b. Ferh. elCâmi' li ahkâmi'l-Kur'ân. Thk. Ahmed el-Berdûnî - İbrahim Itfiyyiş. 10 Cilt. Kâhire: Dâru'l-kütübi'l-misriyye, 1964.

Mâverdî, Ebu'l-Hasan Ali b. Muhammed. en-Nüketü ve'l-uyûn. Thk. Seyyid b. Abdilmaksûd b. Abdirrahim. 6 Cilt. Beyrut: Dâru'lkütübi'l-ilmiyye, ts.

Mürsî, Ebu'l-Hasen Ali b. İsmail b. Sîde. el-Muhassas. Thk. Halil İbrahim Ceffâl. Beyrut: Dâru ihyâi't-türâsi'l-Arabî, 1996.

Nesefî, Ebü'l-Berekât Hâfızüddîn Abdullah b. Ahmed b. Mahmûd. Medârikü't-tenzîl ve Hakâiku't-te'vîl. Thk. Yusuf Ali Bedîvî. 3 Cilt. Beyrut: Dâru'l-kelimi't-tayyib, 1998.

Özdeş, Talip. Cinsiyet Kimliği. Sivas: Seyran Yayınları, 2000.

Özek, Ali - Karaman, Hayrettin - Turgut, Ali - Çağrıcı, Mustafa Dönmez, İbrahim Kâfi - Gümüş, Sadrettin. Kur'ân-ı Kerîm ve Açıklamalı Meâli. Ankara: Türkiye Diyanet Vakfı Yayınları, 1997.

Öztürk, Mustafa. Kur'an-ı Kerim Meali. Ankara: Ankara Okulu Yayınları, 2016, 667.

Râzî, Ebû Abdillâh (Ebü'l-Fazl) Fahrüddîn Muhammed b. Ömer b. Hüseyn. Mefâtîhu'l-ğayb. 32 Cilt. Beyrut: Dâru ihyâi't-türâsi'l-Arabî, h. 1420.

Sa'lebî, Ebû İshak Ahmed b. Muhammed b. İbrahim. el-Keşf ve'l-beyân an tefsîri'l-Kur'ân. Thk. Ebû Muhammed b. Âşûr. 10 Cilt. Beyrut: Dâru ihyâi't-türâsi'l-Arabî, 2002.

Sarıcık, Murat. Put. İstanbul: Nesil, 2014.

Sem'ânî, Ebu'l-Muzaffer Mansur b. Muhammed. Tefsîru'l-Kur'ân. Thk. Yâsir b. İbrahim - Ganîm b. Abbas b. Ganîm. 6 Cilt. Riyad: Dâru'lvatan, 1997.

Semerkandî, Ebulleys Nazr b. Muhammed b. Ahmed. Bahru'l-ulûm. 3 Cilt. (b.y.: y.y., ts.)

Sülün, Murat. “Tefsir İlim midir? Nasıl Bir İlimdir?". Tefsir Nasıl Bir İlimdir?. Ed. Murat Sülün. 11-37. İstanbul: Ensar Neşriyat, 2011.

Sülün, Murat. Kur'an-ı Kerim ve Türkçe Anlamı. İstanbul: Çağrı Yayınları, 2012. 
R. O. ÖZEL / A Male-Dominant Interpretation and Evaluation in Tafsir: Review in the Context of az-Zukhruf $43 / 18$ of the Quran I 77

Tekin, Ahmet. Lügatli Tefsiri Meal. İstanbul: Kelam, 2010.

Usta, İbrahim. İslam Öncesi Arap Mitolojisi. Ankara: Ankara Okulu, 2019.

Yavuz, A. Fikri. Kur'ân-ı Kerîm ve Meâl-i Âlîsi. İstanbul: Doğan Matbaacilik, 1977.

Yazır, Elmalılı Hamdi. Hak Dini Kur'ân Dili. 10 Cilt. İstanbul: Eser Neşriyat, ts.

Zemahşerî, Ebu'l-Kâsım Mahmud b. Ömer. el-Keşşâf an hakâikı ğavâmidı'ttefsîr. 4 Cilt. Beyrut: Dâru'l-kitâbi'arabî, h. 1407. 